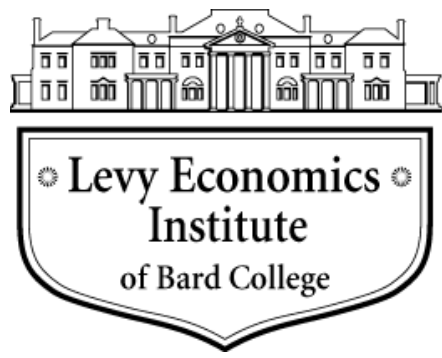

Working Paper No. 966

\title{
Developing a Macro-Micro Model for Analyzing Gender Impacts of Public Policy
}

by

\author{
Jerome De Henau \\ Open University, UK
}

and

Susan Himmelweit

Open University, UK

August 2020

The Levy Economics Institute Working Paper Collection presents research in progress by Levy Institute scholars and conference participants. The purpose of the series is to disseminate ideas to and elicit comments from academics and professionals.

Levy Economics Institute of Bard College, founded in 1986, is a nonprofit, nonpartisan, independently funded research organization devoted to public service. Through scholarship and economic research it generates viable, effective public policy responses to important economic problems that profoundly affect the quality of life in the United States and abroad.

\author{
Levy Economics Institute \\ P.O. Box 5000 \\ Annandale-on-Hudson, NY 12504-5000 \\ http://www.levyinstitute.org
}

Copyright (C) Levy Economics Institute 2020 All rights reserved

ISSN 1547-366X 


\begin{abstract}
This paper discusses new methods of combined macro-micro analysis of labor demand and supply to investigate the gender impacts of public policy. In particular it examines how studies have used input-output analysis together with more or less sophisticated methods of allocating people to jobs to model the impact of public investment in care on the gender employment gap and other inequality measures. It presents some results of a cross-country comparison of investment in the care and construction industries, suggesting methodological refinements to take account of the labor supply effects of such investment policies in order to enable a more detailed analysis of who gets the jobs generated and under what conditions of employment to achieve a more accurate assessment of a policy's full impact on employment inequalities. We argue that such a microsimulation of who is likely to get any newly created jobs should be able to take account of the (child)care "tax" paid by those with caring responsibilities on time spent in employment (as well as the formal tax and benefit system).
\end{abstract}

KEYWORDS: Care; Microsimulation; Public Investment; Labor Demand; Gender

JEL CLASSIFICATIONS: E17; J16; J21; R15 


\section{INTRODUCTION: WHY WE NEED TO BE ABLE TO ANALYZE THE GENDER IMPACTS OF POLICY}

Understanding the gender impact of policies is not only important for those primarily designed to reduce gender equality, but for all policies whatever their aims. Recognizing and quantifying differential gender impacts on a number of dimensions, including on income, earnings, working hours, skill levels, employment incentives, and unpaid work contributions, is the first stage in mitigating any worsening effects on corresponding gender inequalities and in choosing policies that ameliorate them. Legislation in some jurisdictions, such as the United Kingdom and European Union, requires this to be done wherever possible (European Commission 2010; Reed and Portes 2014).

Understanding potential gender impacts on a number of dimensions can also improve the efficiency of policymaking because men and women, occupying different social positions and differently affected by social norms, differ in their behavioral responses to any policy change (Seguino 2013; Himmelweit 2002, 2007; De Henau and Himmelweit 2013a, 2013b). Evidence from developing countries has repeatedly shown the negative effects reforms that were not gender aware can have on growth, employment, and productivity (Elson 1995; Fontana and Rodgers 2005; Seguino 2000). Gender impact analysis can also be used proactively to propose ways of meeting other goals and targets that also reduce gender inequalities.

However, the development of gender-sensitive models that can be used as tools for gender impact assessment is still in its infancy. This paper attempts to make a contribution toward developing the range of models that can be used in assessing the impact of government expenditure policies on gendered employment inequalities so that more aspects of gender difference and dimensions of inequality can be taken into account. Different models are needed for the assessment of different policies, so this paper focuses on how authors, including ourselves, have modeled the gender impacts of a particular type of policy - namely, government investment in care provision, as an example of investment in what we call the "social" sectorand, in many cases, contrast them with those of a similar scale of investment in another industry. This paper presents the headline results of our own study and comments on methodological 
differences with other studies in order to assess some limitations common to them all and suggest where such modeling could advance in the future.

This paper examines how studies have used input-output analysis together with more or less sophisticated methods of allocating people to jobs to model how a policy's labor demand effects impact on the gender employment gap and other inequality measures. We suggest methodological refinements to take account also of the policy's labor supply effects to achieve a more accurate assessment of its full impact on employment inequalities, as well as a more detailed analysis of who gets the jobs that are generated and under what conditions of employment. We argue that such a micro-simulation of who is likely to get any newly created jobs should take account of the effect of any changes in the (child)care "tax" paid by those with caring responsibilities (as well as in the formal tax and benefit system) given the time spent in employment.

The structure of the paper is as follows. The next section looks at why investment in care services, and more generally in the social infrastructure, makes a good case study for developing gender-sensitive policy analysis tools. This is followed by a review of some stylized facts about the social sector, and the care industry in particular, and how it differs from other sectors of the economy. Then we proceed with an illustration of comparative gender impact analysis at the macro level by comparing the gendered employment effects of investing in care services versus construction across a number of countries. This then leads us to consider a method, developed by the Levy Economics Institute of Bard College, of how to assign the jobs created by an investment policy to those persons available for employment, and how this method can be extended to account for both the labor supply and labor demand effects of such a policy. The last three sections of the paper discuss the features of a model that would account for these effects in the context of investing in childcare services, namely the lifting of childcare constraints for those taking on employment, the behavioral reactions of those already in employment, and the induced effects from increased consumption of those taking the new jobs. The last section concludes. 


\section{WHY MODEL THE GENDER IMPACTS OF INVESTMENT IN CARE?}

Many Western economies are currently facing a crisis of care provision with rising care needs, but falling availability of younger women to provide unpaid care. Further increases in earnings inequality means that more of those with caring responsibilities cannot afford to purchase care on the market to enable them to take as many hours of employment as they would like. Many governments and the European Union itself want to increase employment levels in order to increase tax revenues and cut benefit spending, but see caring responsibilities as the main obstacles to raising employment rates, particularly for mothers and those over the age of 50 (European Commission 2010).

Investing in care is therefore on the agenda of most European countries and not specifically on gender equality grounds. However, care policy has also been a longstanding interest of the feminist movement, precisely because it has clear gender equality implications, as in all countries the majority of both paid and unpaid care workers are women, and the majority of long-term care recipients are as well. Because it is a policy with gender implications, but often pursued for other reasons, care policy makes an ideal case study for developing gender-sensitive policy analysis tools. It is also the prime example of a policy affecting the "social sector," a sector that straddles the paid and unpaid economies and contributes to the development of human beings and their socialization. It includes the provision of education and health care, as well as long-term care and childcare.

Using terms "investment" and "infrastructure" for spending on the social sector is in line with the requirement that for spending to count as investment it must create a stock that continues to deliver long-term benefits, and that when these include public benefits it then counts as infrastructure (Himmelweit 2016). However, this is not the case for the distinction drawn between capital and current expenditure in the internationally agreed System of National Accounts (SNA) that records measures of economic activity. In the SNA, investment in physical infrastructure - such as in building bridges, schools, hospitals, or nurseries, including spending on the wages of the builders employed on such projects - counts as capital formation. However, spending on building up social infrastructure and the nation's stock of human and social capital, as well as running and staffing the schools, hospitals, and nurseries, does not count as 
investment, and correspondingly neither does spending on the wages of teachers, nurses, and childcare workers. Instead such spending is considered as part the government's annual current spending. This is perverse because the benefits from today's spending on health, education, and childcare last well into the future and not all these benefits are private; society as a whole gains from having a better educated, healthier, and a better cared for population and from a system that delivers such benefits. For these reasons we term this form of expenditure "investment in social infrastructure." The SNA classification fails to recognize the long-term productive contribution that spending on social infrastructure builds through creating and maintaining the stock of human and social capital.

This distinction matters because in recessionary times policymakers look for effective forms of investment in order to stimulate the economy and generate employment. To be effective in these ways, spending does not need to be investment, but it is obviously desirable that it has long-term benefits. However, investment in social infrastructure is rarely considered for those purposes. In fact, the opposite has happened and public expenditure on education, health, childcare, and longterm care services has been cut in many countries as part of government deficit-reduction strategies. Although governments had begun to recognize, from the mid-2000s, that spending on education and health could be seen as social investment because it improves the productive capacity of the economy, they did not consider changing the accounting rules that would allow such expenditure to be counted as capital spending. Nor, indeed, did they see long-term care services in the same way, especially care for the elderly, where the link between spending and (re)building productive capacity is less obvious than in the case of education. ${ }^{1}$

\footnotetext{
${ }^{1}$ However, a long-term care system could be seen as a contract between generations and an insurance system for the population as a whole to cover any care needs they might have in the future. Paying for such a system would then be an investment in the well-being of the whole population, who would be able to get on with contributing to society in other ways, reassured that their own and their relatives' care needs will be well provided for.
} 


\section{SOME STYLIZED FACTS ABOUT INVESTMENT IN THE SOCIAL SECTOR, PARTICULARLY IN CARE}

In common with other authors, we propose to think of the paid economy as divided into two sectors (Braunstein, van Staveren, and Tavani 2011; Onaran 2016). The first is the social sector, as defined above, whose output contributes to the development of human beings and their socialization by building social and human capital. Both governments and households may invest in this sector, and thereby build the country's "social infrastructure," whether directly by employing workers themselves or indirectly by buying services from private sector providers. Members of households also invest in the country's social infrastructure by providing similar services to family or community members without pay.

The second sector, the "nonsocial sector," makes up the rest of the paid economy. This sector includes, among other industries, those such as construction or telecommunications, whose output is typically recognized as constituting the nation's infrastructure, but which we would call "physical infrastructure" to distinguish it from social infrastructure, though only some of this sector's output consists of investment goods that contribute to building physical infrastructure.

There are some crucial differences between the social sector and the nonsocial sector that we can see as stylized facts to be successively incorporated in a two-sector, gender-sensitive macro model.

First, and crucially, industrial and occupational segregation means that the social sector typically employs a larger proportion of women than men and the nonsocial sector typically employs mostly men. More precisely, all else equal, a woman in employment has a greater propensity to be working in the social sector than a man does. This is particularly true of the care industry. A large number of explanations abound for this gendered sectoral segregation; broadly the concentration of women in the social sector is seen as being due to a combination of employers in the sector finding women to be preferable workers, men being discouraged from working in the sector by its working conditions or by gender norms, and women themselves (also influenced by gender norms) choosing such work either because they find its content congenial or because it can be more easily combined with unpaid caring responsibilities. 
The second and closely related characteristic of the social sector is that for a given level of qualifications, workers in the social sector-particularly care workers - tend to be worse paid than in other sectors. This is the case in many, but not all, countries (England, Budig, and Folbre 2002; Budig and Misra 2010). It is not clear why such a "care" or "social" penalty may exist. One explanation is that some of the emotional skills required for work in the sector are unrecognized and unrewarded, perhaps because they are acquired in the home and/or seen as feminine characteristics (Phillips and Taylor 1980; England 2005). At any rate, the relationship between female domination of employment in the social sector and its relative pay is complex and could be modeled in a number of different ways.

Thirdly, the two sectors differ in the nature of their labor processes, with many of those in the social sector tending to be highly labor intensive and using relatively few material inputs. Indeed, the provision of care is almost all labor. This is less true of medical care where some very hightech equipment is used. Nevertheless, the wage bill is likely to be a substantial proportion of total costs throughout the social sector.

A fourth difference is that much of the social sector's labor process is relational, for which the possibilities of labor-saving technical change are much more limited. Faster productivity growth is therefore to be expected in the nonsocial sector (Baumol and Oates 1972). This may in turn mean that wage increases in the social sector lag behind those in the nonsocial sector.

Fifthly, the sectors also differ in how their output affects productivity. Increased output by either sector may result in greater productivity in the economy as a whole in the long run. Parts of the nonsocial sectors produce physical investment goods and infrastructure that will allow labor to be employed more productively in the future. Much of the output of the social sector also has an effect on future productivity through improving the quality of the labor force, giving them the health care, skills, and education to make them more productive paid and unpaid workers. In particular, childcare and preschool education have a significant human capital impact (Heckman, Pinto, and Savelyev 2010, 2013). The two sectors both have productivity-enhancing effects, but in quite different ways, and we have no reason to assume one to be larger than the other. However, if we are moving into a period in which knowledge production outstrips material 
production, then it may be that the productivity-enhancing effect of investment in the social sector will grow relative to that of the nonsocial sector.

The sixth stylized difference between the two sectors is the most telling for this paper. The output of the social sector not only enhances the quality of the future labor force, it quantitatively expands current labor supply. The output of any part of the social sector may enable more people to join the labor force; a healthier population, for example, will have more people fit for employment. However, it is the care industry that most directly helps boost the labor supply by enabling care recipients and their families to access alternative care (either by purchasing it on the market or through public provision) so that those currently devoting time to unpaid care can be freed for some of that time to take employment. Since nearly all those whose care responsibilities restrict their employment opportunities are women, relieving them of some of those responsibilities should have an effect on both overall labor supply and on the gender composition of that labor supply (Del Boca and Pasqua 2005; Del Boca and Vuri 2007; Apps and Rees 2004, 2005).

The nonsocial sector can also have such effects. For example, the provision of transport enables people who might otherwise not be able to get to their jobs to take employment. Nevertheless, it is clear that while some output of the nonsocial sector could help expand the current labor supply, many industries within that sector (for example, construction) will have only indirect labor supply effects, if any. In a modern economy few people are directly restricted from taking employment by doing unpaid work that substitutes for the products of the nonsocial sector, unlike the products of the social sector, many of which directly substitute for unpaid care work.

Finally, the sectoral composition of where men and women spend any additional income from increased employment may also differ, because women may need to spend more of their earnings on local services to replace the unpaid work they were previously doing (assuming not all needs are covered by free public provision). In other words, those with caring responsibilities may pay a (child)care "tax" on their time spent in paid employment, mainly for the outputs of the social sector that replace their unpaid work. Further, because of the gender wage gap and shorter hours of employment, on average women tend to have lower incomes than men and so can be assumed to save less. Both effects would lead to a somewhat greater short-term multiplier effect 
on aggregate demand from women's employment than from men's, and consequently from investment in the social as opposed to the nonsocial sector, though the extent to which the former substitutes for the need to buy replacement care services and raises women's household incomes will affect that multiplier.

In summary, compared with the nonsocial sector, the social sector is the sector:

(1) in which women have a greater propensity to be employed than men;

(2) that pays lower wages for given levels of qualifications;

(3) that is more labor intensive and uses fewer material inputs;

(4) in which there are relational labor processes that restrict opportunities for productivity increases and wages correspondingly rise more slowly;

(5) whose output has a positive effect on the opposite sector's productivity in the long run;

(6) whose output has a positive effect on labor supply, particularly women's labor supply; and

(7) from which women have a greater propensity to consume than men do.

\section{A STUDY FOR THE INTERNATIONAL TRADE UNION CONFEDERATION (ITUC)}

To create the most basic two-sector, short-term model, we could initially ignore the dynamic and long-term stylized facts (4) and (5) in the above list. Also, for a purely demand-side model, stylized fact (6) (that the output of social sector can substitute for paid work to free people for employment) can be set aside; such supply-side effects are not relevant to the quantity of jobs generated, but crucial to who gets those jobs and therefore the gender employment gap.

The simplest demand-side model would then take the remaining stylized facts to be represented by exogenously given parameters, by assuming that current production coefficients, wages, and proportions of men and women employed in each sector continue to apply to any newly generated employment. We might further assume that propensities to consume from each sector remain unchanged and uniform across households (i.e., not broken down by gender or anything else). Using such a model, we could also examine the effect of changing any of those parameters while keeping them exogenous. 
Even as basic a model as this enables us to predict effects on total employment, on employment levels of each gender, and, hence, on the gendered employment gap. It could also be used to predict the shares of employment and output in each of the two sectors, and thus the levels for the economy as a whole of any other characteristics of jobs that are assumed to be exogenous for each sector (e.g., their level of nonstandard contracts or the age structure of their work force). However, such a model would not allow us to analyze any within-sector changes, including the gender composition of their workforces or gendered wage levels. Any changes in these variables for the economy as a whole would be simply due to changes in the employment share of the two sectors.

This was the approach we, together with our coauthors Zofia Łapniewska and Diane Perrons, took on an international comparative study (De Henau et al. 2016) conducted for the International Trade Union Confederation (ITUC), a summary of whose results are given below. Input-output tables and other official statistics based on a snapshot of the economy were used to calculate the employment effects of an investment equal to 2 percent of GDP made to either the care or the construction sector, taking these two sectors as typical examples of where social and physical infrastructure investment, respectively, is made. ${ }^{2}$ This is similar to the approach taken by Antonopoulos et al. (2011) and Ilkkaracan, Kim, and Kaya (2015), among others.

We estimated direct, indirect, and induced employment effects. The last of these is the employment induced by the spending of additional workers employed directly in the industry in which the investment was made and indirectly in the industries supplying it. We also looked at the gendered breakdown of each of these employment effects and the gender employment gap.

To do all this required making the strong assumptions about the exogeneity of variables of the basic model described above. The use of input-output tables implies fixed production coefficients and we took the gender composition of each sector and relative wage levels to remain where they were in the most recent year for which employment surveys were available. The way induced employment effects can be calculated from input-output tables- by treating

\footnotetext{
${ }^{2}$ Compared with a genuine two-sector model, our results depend on the representativeness of the industries chosen to represent each sector. For the United States and the United Kingdom, our results will somewhat overestimate the employment effects of investment in both sectors, since care and construction are both worse paid and more labor intensive than most other industries in their respective sectors.
} 
households as one undifferentiated industry - meant that we could not estimate differential induced effects for men's and women's employment or for workers at different wage levels. Our estimates of the induced effects of investment in any industry are therefore simply proportional to the wage bill generated by that investment's direct and indirect effects.

As far as we are aware, ours is the first study to calculate such effects across countries in a directly comparable way. Our results cover seven high-income OECD countries-Australia, Denmark, Germany, Italy, Japan, the United Kingdom, and the United States - chosen to reflect different regions of the world, different systems of economic and social regulation, and because of data availability. The reference year of the input-output tables is 2010 for the United Kingdom, Italy, and Germany; 2011 for Denmark and Japan; 2012 for Australia; and 2013 for the United States. ${ }^{3}$

\section{Employment Effects}

Table 1 gives the employment effects by country, that is, the number of new jobs directly generated by an investment equivalent to 2 percent of each country's GDP in the construction or the care industries. Since countries differ in the size of their working-age population, the easiest way to compare effects is to give the numbers of newly employed people as a percentage of each country's working-age population (15-64 years), or the percentage points by which its employment rate would rise.

\footnotetext{
${ }^{3}$ A second study, funded by the ITUC and UN Women was subsequently carried out comparing the gendered employment effects of investing in the "health and care" and "construction" sectors of six "emerging economies" (De Henau, Himmelweit, and Perrons 2017).
} 
Table 1. Employment Effects: Percentage Point Rise in Headcount Employment Rate through an Investment of 2 Percent of GDP in Care and Construction Industries

\begin{tabular}{|c|c|c|c|c|c|c|c|c|}
\hline & \multicolumn{4}{|c|}{ Construction } & \multicolumn{4}{|c|}{ Care } \\
\hline & Direct & Indirect & Induced & Total & Direct & Indirect & Induced & Total \\
\hline Australia & 0.5 & 1.2 & 0.9 & 2.5 & 2.3 & 0.3 & 1.4 & 4.0 \\
\hline Denmark & 0.8 & 0.5 & 0.6 & 1.9 & 2.1 & 0.3 & 0.9 & 3.2 \\
\hline Germany & 0.9 & 0.5 & 0.5 & 1.9 & 2.6 & 0.3 & 0.8 & 3.7 \\
\hline Italy & 0.6 & 0.7 & 0.3 & 1.6 & 1.4 & 0.5 & 0.5 & 2.4 \\
\hline Japan & 1.4 & 0.7 & 1.7 & 3.8 & 2.0 & 0.5 & 1.8 & 4.3 \\
\hline UK & 0.7 & 0.6 & 0.5 & 1.8 & 1.8 & 1.2 & 0.7 & 3.7 \\
\hline US & 1.2 & 0.7 & 1.6 & 3.5 & 3.4 & 0.6 & 2.1 & 6.1 \\
\hline
\end{tabular}

Source: De Henau et al. (2016)

Table 1 shows that the direct employment effects of an investment in care are considerably larger than those of an equivalent investment in construction. Our stylized facts point to a number of reasons why this is to be expected. First, because care is a more labor-intensive industry than construction, which uses a number of inputs other than labor, the majority of the costs of providing care consist of care workers' wages and relatively little equipment and raw materials are needed. Second, as table 2 shows, in some countries, but not Japan, workers in the care industry (particularly those providing care directly) are paid at a lower rate than many construction workers: not much lower in most countries, but in the United Kingdom and the United States there is a large difference in wage levels, and a given amount of investment spending will employ considerably more care workers than construction workers. ${ }^{4}$ Finally, on average, care workers are employed for shorter hours than construction workers, since many care workers are employed part time or for variable hours (e.g., on zero-hours contracts), so on the assumption made that this does not change, the same number of employment hours will require more workers to be employed in care than in construction.

\footnotetext{
${ }^{4}$ Note the difference from our stylized fact (2): that care should pay lower wages than construction for given levels of qualifications. Table 2 shows that care actually pays lower wages overall than construction, with differences between countries in the pay ratio reflecting in part the different qualifications required of care workers, which vary considerably across the countries investigated.
} 
Table 2. Compensation of Employees per Full-Time Equivalent (percent of average compensation)

\begin{tabular}{lrrr}
\hline & Construction & Care & $\begin{array}{c}\text { Ratio care / } \\
\text { construction }\end{array}$ \\
\hline Australia & 108 & 106 & 97 \\
Denmark & 90 & 85 & 94 \\
Germany & 79 & 70 & 88 \\
Italy & 76 & 69 & 90 \\
Japan & 73 & 81 & 112 \\
UK & 100 & 44 & 44 \\
US & 70 & 38 & 54 \\
\hline
\end{tabular}

Source: De Henau et al. (2016)

There is some variation between countries in the size of these effects, with the direct employment effects of investment in construction ranging from half a percentage point of the headcount employment rate in Australia to 1.4 percentage points in Japan. The range is somewhat bigger for the care sector, ranging from less than 2 percentage points in Italy and the United Kingdom to more than 3 percentage points in the United States. ${ }^{5}$ What counts as a direct employment effect partly depends on the internal contracting structure of an industry. Where workers are indirectly employed through contracting out, their employment appears as an indirect effect, so some of the variation in the size of direct employment effects could be a result of the internal structure of the industries varying across countries. Outsourcing within the industry will reduce direct employment effects but will increase indirect effects.

In most countries, the indirect employment effects of investment in construction are larger than those in care. This was to be expected from our stylized facts, because care uses fewer material inputs than construction. Two outliers are worth discussing at this point: the care effect for the United Kingdom and the construction effect for Australia.

The much larger indirect effect of care in the United Kingdom is nearly all ( 0.8 percentage points) due to indirect employment effects within the care sector, ${ }^{6}$ meaning that the care sector in the United Kingdom outsources a larger proportion of its inputs within itself than the care sector in other countries (and indeed than the construction sector in many countries). One possible explanation for this is the recent intense privatization of care in the United Kingdom — such

\footnotetext{
${ }^{5}$ Note that for the US calculations we used the number of jobs rather than the number of people employed, therefore marginally overestimating the employment rate effects.

${ }^{6}$ This can be seen by estimating own-industry effects (not shown).
} 
restructuring may lead to greater outsourcing and contracting through agencies. This is consistent with the direct employment effect in the United Kingdom being lower than most, so that the sum of the total within-industry effects (both direct and indirect) is consistent with that of the other countries studied.

The other outlier is Australia, whose residential construction sector generates particularly large indirect employment effects (and the lowest direct employment effect). This seems to reflect recent changes in the Australian construction industry, resulting in increased outsourcing to specialized trades in other industries and subcontracting between firms within the construction sector (Toner 2006).

Besides indirect effects there are also induced employment effects as a result of the additional household income generated by the new employment. Because we have had to treat all household income as being spent in the same way, as is the usual practice by those statistical offices that calculate induced effects, ${ }^{7}$ these induced effects are simply proportional to the total wages of the employment generated by direct and indirect employment effects. That the induced effects of investment in the care sector are larger than those of the construction sector reflects the larger overall employment effects of the care sector outweighing its lower pay. Our stylized facts suggest that, all else equal, income going to women is more likely to be spent and more likely to be spent on the products of the care sector than income going to men. But a substantial investment in care might reduce the need for women to spend their money in this way. We can therefore expect that the induced employed effects for investment in care might differ from those given in table 1, but it is impossible to predict in which direction, since the direct and indirect employment effects generate more jobs for women (see table 3 ) but, on the other hand, the investment itself might reduce women's expenditure on care.

We can see that in all countries the total employment generated by investment in care is large, and far larger than that of an equivalent investment in construction, which is one of the industries that tend to be thought about first when an employment stimulus is proposed. The effect of investment in care is at least 50 percent larger in all countries except Japan, where investment in

\footnotetext{
${ }^{7}$ We have broadly followed National Statistics Scotland's methodology, adapting it where necessary to the data limitations of particular countries. For further details, see appendix 2 of the ITUC report (De Henau et al. 2016) 
construction has unusually large employment-generating effects (both direct and indirect) because construction is exceptionally badly paid, even worse than care, as table 2 showed. In Italy the headcount employment effects for both sectors are smaller (more so for care) than for other countries, with both direct and induced effects amongst the smallest. This is in part due to a larger proportion of full-time employment than in the other countries. Another reason might be that because long-term care in Italy is so underdeveloped, with formal domiciliary care virtually nonexistent, the more capital-intensive residential care might dominate official statistics giving a lower direct employment effect in Italy than in, say, Germany, even though relative wages are of the same magnitude in both countries (table 2). It is unlikely that the input-output tables capture the contribution of the grey economy, which is widely developed in Italy's long-term care system. ${ }^{8}$

Note that a model of this simplicity, which was necessary in order to get reliable comparable data, does not allow for any effects on working conditions (and pay) within either sector that such a massive injection of demand would be expected to generate, particularly if the sector was already experiencing recruitment and retention problems due to poor pay and conditions. This is the case in the care industry in many countries, so while the total amount of employment generated in the care industry may be less than our estimates, the jobs generated should be of higher quality. We also could not allow for any use of labor-saving technology. Our results therefore somewhat overestimate the number of jobs generated, though our stylized facts about where labor-saving technology is more likely to boost productivity suggest that this overestimation would be greater for the construction industry.

\section{Gender Effects}

Table 3 shows that the direct gender employment effects of investment in the two industries are quite different. Both industries are heavily gender segregated, particularly construction. As a result, only 6 percent to 14 percent of the jobs directly generated in construction would go to women in our simulation. Care is almost as gender segregated but in the opposite direction.

\footnotetext{
${ }^{8}$ For more details and sources, see the country profile in appendix 1 of the ITUC report (De Henau et al. 2016).
} 
It is striking that the indirect employment generated by the construction industry is still male dominated, though less so than its direct employment. For the care industry that is not the case. Indeed the balance of indirect employment generated if anything favors men somewhat, except in the United Kingdom where, as mentioned above, there is a large indirect effect primarily within the care sector itself, which as we know is female dominated.

Table 3 reveals how, as mentioned above, the only difference in the induced effects of the investment between the two industries that our methodology can pick up is one of scale: the percentage of the jobs generated in each industry and therefore their gender breakdown is the same across both industries.

Table 3. Gendered Employment Effects: Percent of Jobs Generated Taken by Women Construction Care

\begin{tabular}{lrrrrrrrr}
\hline & Direct & Indirect & Induced & Total & Direct & Indirect & Induced & Total \\
\hline Australia & 11 & 30 & 49 & 33 & 79 & 42 & 49 & 66 \\
Denmark & 8 & 31 & 47 & 27 & 81 & 42 & 47 & 69 \\
Germany & 13 & 33 & 51 & 28 & 75 & 50 & 51 & 68 \\
Italy & 6 & 24 & 44 & 21 & 85 & 53 & 44 & 70 \\
Japan & 14 & 34 & 43 & 30 & 77 & 42 & 43 & 59 \\
UK & 11 & 23 & 46 & 24 & 80 & 67 & 46 & 69 \\
USA & 13 & 37 & 52 & 35 & 81 & 43 & 52 & 67 \\
\hline Sourc
\end{tabular}

Source: De Henau et al. (2016)

The direct effect of investing in care would therefore be to reduce the gender gap in employment for the economy as a whole. To see the effect of investment in a sector on the employment rate of men and women, the size of the employment effects from table 1 has to be combined with the percentage of jobs taken by each sex from table 3. Table 4 shows the total effects on the employment rates of women and men, as well as the gender employment gap. Thus, investment in care would result in an increase in the employment rate of women of between 3.3 percentage points and 8.2 percentage points, while for men that rise is considerably smaller in all countries (though still larger than that for women of investing in construction), reducing every country's gender gap in employment by at least 1.6 percentage points. For construction the gender effects are reversed and the gender employment gap rises. But the effect of investment in care on men's employment rate is much greater than that of investment in construction on women's 
employment rate because of the former's greater total employment effects (see table 1). And in Germany, the United Kingdom, and the United States, the rise in the employment rate for men from investing in the care sector is not far off that of an equivalent investment in the construction sector.

Table 4. Gendered Total Employment Effects: Percentage Point Changes

\begin{tabular}{lrrrrrrr} 
& \multicolumn{3}{c}{ All } & \multicolumn{3}{c}{ Construction } & \multicolumn{3}{c}{ Care } \\
& $\begin{array}{c}\text { Existing } \\
\text { gender emp. } \\
\text { gap }\end{array}$ & $\begin{array}{c}\text { Rise in } \\
\text { women's } \\
\text { emp. rate }\end{array}$ & $\begin{array}{c}\text { Rise in } \\
\text { men's } \\
\text { emp. rate }\end{array}$ & $\begin{array}{c}\text { Change in } \\
\text { gender } \\
\text { emp. gap }\end{array}$ & $\begin{array}{c}\text { Rise in } \\
\text { women's } \\
\text { emp. rate }\end{array}$ & $\begin{array}{c}\text { Rise in } \\
\text { men's } \\
\text { emp. rate }\end{array}$ & $\begin{array}{c}\text { Change in } \\
\text { gender } \\
\text { emp. gap }\end{array}$ \\
\hline Australia & $\mathbf{1 2 . 2}$ & 1.7 & 3.4 & $\mathbf{1 . 8}$ & 5.3 & 2.8 & $\mathbf{- 2 . 6}$ \\
Denmark & $\mathbf{6 . 5}$ & 1.0 & 2.7 & $\mathbf{1 . 7}$ & 4.5 & 2.0 & $\mathbf{- 2 . 5}$ \\
Germany & $\mathbf{9 . 4}$ & 1.1 & 2.8 & $\mathbf{1 . 7}$ & 5.1 & 2.4 & $\mathbf{- 2 . 7}$ \\
Italy & $\mathbf{2 1 . 1}$ & 0.7 & 2.5 & $\mathbf{1 . 8}$ & 3.3 & 1.4 & $\mathbf{- 1 . 9}$ \\
Japan & $\mathbf{2 3 . 1}$ & 2.3 & 5.3 & $\mathbf{2 . 9}$ & 5.1 & 3.4 & $\mathbf{- 1 . 6}$ \\
UK & $\mathbf{9 . 9}$ & 0.9 & 2.7 & $\mathbf{1 . 8}$ & 5.1 & 2.3 & $\mathbf{- 2 . 8}$ \\
USA & $\mathbf{8 . 7}$ & 2.5 & 4.6 & $\mathbf{2 . 1}$ & 8.2 & 4.0 & $\mathbf{- 4 . 2}$ \\
\hline S0urce & & & & & & &
\end{tabular}

Source: De Henau et al. (2016)

As a result, while investment in construction increases the gender employment gap, investment in care reduces it substantially while increasing both women's and men's employment rates. The relative reduction in the employment gap is strongest in the United States and Denmark, where existing employment gaps are the lowest, whereas the gaps are least reduced in Italy and Japan, where they are the largest of the seven countries studied.

\section{ASSIGNING NEW JOBS TO INDIVIDUALS}

By using input-output tables, the ITUC study uses a simplified version of the method used in a series of country policy simulations on South Africa (Antonopoulos and Kim 2008), the United States (Antonopoulos et al. 2011; hereafter AKMZ), and Turkey (Ilkkaracan, Kim, and Kaya 2015; hereafter IKK) to calculate the direct and indirect employment effects of investment in care and construction. However, these earlier studies are more complex in that they then use the "Levy microsimulation method," outlined below, to allocate people to the newly created jobs according to their personal circumstances and characteristics, including gender. Like the ITUC 
study, this method assumes there are no overall labor supply constraints and therefore that all jobs can be filled. Unlike in the ITUC study, using the Levy method allows employment ratios by gender to change within each sector as a result of the job allocation process.

This should be a more accurate way of capturing the gender impact of investment in an industry. By estimating gendered employment effects to be proportional to the gender composition of the existing workforce in each industry, our ITUC analysis assumed the newly employed in each industry had just the same characteristics (and constraints to overcome in being employed) as those already employed. But this is unlikely to be the case. The pool of those looking for work are not just like those in work, since the latter had already succeeded in being employed-either because of personal characteristics that made them more desirable employees or because of circumstances that made employment feasible or more worthwhile for them. In the latter respect, the economically inactive are likely to differ even more than the unemployed from those who are in employment. It therefore makes sense to use the characteristics of those who are, in practice, available to take the newly created jobs in modeling the gender (or any other distributional) effects of the investment in any industry.

The Levy microsimulation method uses data on the personal characteristics and circumstances of both those employed in different occupations in each industry and those in whatever is designated as the pool of those available for employment to match some of the latter to the newly created jobs. On this basis the effects on employment by gender in each sector and on the gender employment gap can then be estimated. Similarly, by estimating wage levels for the newly employed, effects on pay by gender, the gender pay gap, and various other distributional measures can then be calculated.

To do so, it is necessary to divide the newly created employment in each industry into occupations. This is done by dividing employment generated in each industry into "jobs," defined by industry/occupation pairs, in proportion to the existing occupational breakdown of that industry. 
AKMZ describe the subsequent job allocation process:

To assign jobs, we create a statistical ranking of occupations and industries for each individual by estimating the likelihood of being employed in each job category. The method was to estimate a multinomial probit regression for industry and occupation and then predict probabilities for each. ${ }^{[9]}$ For each individual, industries and occupations were ranked based on highest propensity score. Then we estimated likelihood of being employed for each individual, using a probit regression and propensity score ${ }^{[10]}$ With these three sets of information for each individual, we assigned employment status to those in the employable pool using an iterative procedure, stepping through industry and occupation pairs, selecting those individuals most likely to be employed in that industry-occupation pair, in order of their likelihood to be employed, until all the available jobs were assigned. Once we assigned jobs, we allocated earnings to those individuals who received a new job. The method was imputation by hot-decking. ${ }^{[11]}$

Masterson (2013) describes the method of earnings allocation in more detail, giving the different steps that are required to obtain the wage rates and working hours that those allocated jobs can command. It involves a two-step procedure in which the first step uses a three-stage Heckit model to predict imputed wage and working hours for each individual in the employable pool within age-sex cells. Then the hot-decking begins with individuals assigned to cells formed by a combination of age, sex, and educational attainment. Within these cells, "recipients" (the newly employed) are matched to their nearest "donor" (among the already-employed individuals) based on differently weighted criteria (such as, in order, rural/urban, imputed industry-occupation pair, log wages and hours imputed by the Heckit model, family type, and variables relating to presence of children). The recipients are then given the value of the wages and hours and hence earnings of the donor that is their closest match.

\footnotetext{
${ }^{9}$ Independent variables for the industry and occupation multinomial logits were census division, metropolitan status, age, marital status, sex, educational attainment, and race.

${ }^{10}$ Independent variables for the employment probit were census division, metropolitan status, age, age squared, marital status, sex, educational attainment, and race.

${ }^{11}$ A three-stage Heckit model is used to predict imputed wage and usual hours for each individual in the pool within age-sex cells. These, together with census division, metropolitan status, marital status, spouse's labor force status, industry and occupation of assigned job, dummies for age category of youngest child, and the number of children were used in the imputation procedure.
} 
There are some differences between AKMZ and IKK:

1. In AKMZ, the employable pool effectively consists of just the unemployed..$^{12}$ However, in IKK, the employable pool also includes those not in employment for family reasons, so the unemployed plus all those in the 20-65 age group, with no health or disability restriction.

2. More explanatory variables are used in IKK, including:

a. the multinomial probit regression for the propensity to be employed in a particular industry-occupation pair includes as independent variables: a worker's existing employment class (i.e., regular, casual, employee, employer, self-employed, or unpaid family member) and their relationship to household head, as well as equivalent variables to those used in AKMZ; and

b. the probit regression to estimate an individual's propensity to be employed includes as independent variables: their spouse's labor force status, and their own most likely industry/occupation calculated as above.

As noted above, the Levy method provides for a potentially more accurate assessment of the gender impact of an investment stimulus in different industries. However, like our ITUC analysis, its job matching exercise assumes that the pool of employable persons to whom jobs could be allocated will not run out. This is more plausible in a recession, when the pool of people available for employment exceeds the demand for their labor, than when unemployment rates are falling. As the pool of employable persons shrinks, analysis of the effectiveness of employment policies needs to consider their effects on labor supply. To do this, the constraints that individuals face in taking employment need to be modeled. One of the attractions of investment in care, and more widely in the social sector, is that such investment may lift some of the constraints preventing those with caring responsibilities from taking employment at the same time as it generates jobs for them and others to take.

\footnotetext{
${ }^{12}$ AKMZ's employable pool of potential workers consists of individuals (16 years and older) who were not in employment at the time of the census, excluding those who were not employed at all the previous year because of being retired, disabled, taking care of family, or (for those of less than 20 years of age) in school.
} 


\section{ACCOUNTING FOR THE USE OF CHILDCARE}

Neither the studies using the Levy method presented earlier nor our ITUC study explicitly consider what the investment in care actually does, that is, how people and the economy benefit from the output of the investment: the care services themselves. As mentioned above, there are long-term benefits to investing in childcare. These are likely to change the characteristics of those seeking employment, including the constraints that they face. For example, good quality childcare is likely to change the skills of those seeking employment in the future. However, one of the most immediate effects of investment in care and especially in childcare, and thus particularly desirable to include in a short-term model, is the effect on the composition of the pool of people who would like to find employment, because (some of) those whose care responsibilities previously prevented employment would, after such an investment, choose to take employment.

Complex models have been provided in the literature to account for the relationship between childcare provision and financial incentives to take employment, by including as a cost of employment the net cost of childcare to parents, but such models have almost always been limited to a labor supply framework, implicitly assuming no demand shortage (see models by Duncan, Giles, and MacCrae [1999] and Adams and Phillips [2013]). This is the obverse of the Levy/ITUC models. It would be good to reconcile the two approaches by finding a way to model the effect of childcare on labor supply together with its effects on the expansion of employment opportunities.

That said, childcare provision and its effect on labor supply have been the subject of some studies using the Levy method. For example, Zacharias, Masterson, and Kim (2014, henceforth ZMK) have modeled the effect of a job creation program and consequent use of outsourced childcare on time and income poverty in Korea. However, their study was not of the jobs that an investment in care provision specifically would create, nor of how such provision would have changed the characteristics of the pool of employable people. Nor, by assuming that all persons eligible for a job under the program would take one that matched their personal characteristics, did that study model the labor supply decision itself or link it to the availability of childcare that an investment in care would be expected to expand. 
In the IKK study, recognition is specifically made that investment in childcare will change the opportunity for some mothers of young children to take up paid employment. The study estimates the additional effects on income poverty rates of expanded childcare provision by assuming that it enables all poor mothers of young children with previous work experience to take jobs, allocated by the Levy method, assuming unconstrained labor demand. (These effects on income poverty are additional to those due to the jobs created by the demand-side effects of the childcare investment alone.) Effectively the IKK study investigates the effects of investment in childcare on both labor supply and labor demand, but does not have them interact.

Any investment in care entails a particular policy about how the newly provided care places will be allocated, for example making childcare freely available for all preschool children or supporting market provision through means-tested subsidies to parents. An expansion of the Levy method could explicitly account for the way that a particular policy changes the constraints that specific individuals face in taking employment, potentially changing whether they decide to participate in the labor market, and integrate such changes in the job allocation algorithm.

The main group whose constraints may change are those who are not currently in employment for family reasons. Some of those reasons might be changed by a policy providing nonparental care. However, for that change to be sufficient for a parent to join the employable pool, the net gain to employment would have to be sufficiently increased so as to make employment desirable when it was not previously. For some parents, this is not a financial issue. Indeed, some mothers give up large potential earnings to care for their children themselves, but in general the greater the increase in the net gains to employment, the greater the chances of nonparental care arrangements being used in order to take employment. Frequently this is modeled as though the choice is a purely financial one, but allowing for heterogeneity in how much net gain is enough to provoke a change of behavior would be one way to allow for differences in views.

While AKMZ excludes all those not in employment for family reasons from its employable pool, IKK includes them all in their main (demand-side) simulation. In our view, both of these are too extreme. A specific care policy will help with only some care constraints, so a policy providing childcare for preschool children can relieve family reasons as constraints on employment only for those with preschool children in their household and, among those, only for those whose 
family reasons for not being in employment are sufficiently changed by the availability of childcare that they would then desire employment. Further, IKK also includes those not in employment for family reasons in their employable pool for modeling the effects of investment in construction, even though in this case no such care constraints are alleviated; this suggests that the reason for their expanded employment pool is not to do with the effects of the investment in care per se.

In any case, the main issue is not so much the choice of the pool itself but the way in which this pool may change as a result of the investment policy. What is needed is a method that allows us to make some assessment of the potential net gains to employment for individuals. Those with sufficient gains to employment as a result of a specific policy change would then be considered for employment.

The current method could therefore be adapted as follows. We still consider the likelihood of being picked for employment for all those in a potentially employable pool, and proceed with estimating the variables needed for the matching process, that is, industry/occupation pair, hours, and wages, as described above. Whether or not the new jobs will be given to any of these candidates will be determined in order of their likelihood of getting a job. The novelty is that this likelihood would be estimated with an explicit account of the structure of constraints for each individual, what we have called the "net gain to employment," which is allowed to change with different policies. ${ }^{13}$

One simple adaptation of the IKK study's procedure to account for changes in care constraints could therefore be to consider the presence of young children in the estimation of the likelihood of being employed and predict new propensities of being in employment for those mothers with observed preschool children by replacing the estimated value of the coefficient associated with young children with that of older children (in the care investment scenario but not the construction scenario). This method is called "recycled method prediction" and is widely used to

\footnotetext{
${ }^{13}$ This could be done in two ways, yielding similar results. One way is to estimate the likelihood of being in the pool of employable persons and then run the traditional Levy method on a pool consisting of those with an estimated likelihood greater than some cut-off point. The other is to consider the entire pool of persons looking after families (e.g., mothers of preschool children) and estimate their likelihood of being in employment as in the Levy method (exactly as in IKK). Both estimation methods would need to include some explanatory variables that would account for caring constraints and would be allowed to change with different policy scenarios.
} 
simulate various outcomes inter alia using results of nonlinear estimations (De Henau, Meulders, and O’Dorchai 2010).

However, assuming that mothers of preschool children would behave like mothers of older children with otherwise similar characteristics implies that the specific care needs of young children are the only factor limiting their mothers' employability, search, and desire for employment. Leaving aside preferences for now, this simple procedure also assumes that the investment in childcare provision would entirely remove this "care" constraint, which is unrealistic, unless high-quality, free, full-time universal childcare was provided, and compensation was made for all other associated costs of combining employment with responsibilities for small children. Therefore, in order to simulate a wider range of care policy scenarios, the procedure would need to include more variables that explicitly account for varying levels of "care cost and availability" to individuals, and separately so from the other influences that children may have on employment decisions (such as preferences for home time).

Indeed, the likelihood of being employed depends on a series of personal and household characteristics, and in the case of a couple would also depend on their partner's employment characteristics, ${ }^{14}$ alongside usual factors including education, age, race, presence and age of children, and region of residence. Instead of using the presence of preschool children as the proxy for the costs of employment relating to caring constraints — which implicitly assumes the same cost for all mothers - we could include more heterogeneity in the model, starting with local discrepancies in the cost of childcare. Adding a variable for the local availability of affordable childcare could be one step in that direction. This would allow us to isolate the influence of care costs from other influences that the presence of children entails, such as consumption costs and preferences.

A more complete account of financial net gains to employment would include variables such as the individual's predicted wage and, with the appropriate specification, the earnings of their

\footnotetext{
${ }^{14}$ Models vary in the extent to which they take joint decisions in couples into account. One crucial but often empirically neglected aspect (because of complexities and data requirements) is accounting for diverging interests in the couple's decision making and household income that is not entirely pooled.
} 
partner (if any), their household's net nonlabor income, and indicators for the costs of employment including (crucially) the cost/availability of suitable childcare services. ${ }^{15}$

The impact of a specific policy on these variables can be calculated and used in the estimation of the propensity to be employed. For example, the net gain to their household of a certain number of hours of employment by a household member would be the difference between the household's net income after childcare costs for that level of employment and its income when the individual is not in employment. If this gain is affected positively by the policy change, then it is expected that the likelihood of being employed will increase and vice versa. However, to calculate such a net gain to their household requires knowledge of a person's potential wage rate and hours of employment. Therefore, if such gain is to be considered, estimating a likelihood of being in employment can no longer be done prior to estimating wages and hours of employment.

As a result, the procedure needs not only to consider whether a candidate is likely to be employed at all but also at what wages and hours of employment. Following recent developments in the labor supply literature, discrete-choice models that allow for only a limited number of possible hours are more appropriate than models with continuous hours (see Adams and Phillips [2013] for a discussion). Therefore the procedure would be adapted to estimate the likelihood of being employed at each of a number of discrete employment hours (including zero).

Such hours of employment would be determined by individual characteristics and imputed wages. Imputed wages are needed to calculate gross earnings and then net income at different hours as the basis for determining the potential gain from employment after childcare costs. ${ }^{16}$ Typically a full-blown tax-benefit model would be needed to compute these gains, given the complexity of tax-benefit systems in many countries and the nonlinear effects of the interaction

\footnotetext{
${ }^{15}$ Note that more complex labor supply models would jointly estimate the decision to work and to use childcare, allowing for the possibility that formal childcare is being used even when parents/mothers do not work, because of the value they attach to good quality childcare (especially for older preschool children). See Duncan, Giles, and MacCrae (1999) for some examples with UK data.

${ }^{16}$ Imputed wages are calculated in the same way as described in Masterson (2013) and are not expected to be influenced by a change in policy.
} 
of nonuniform tax rates with the means testing of social security benefits and childcare subsidies (Adams and Phillips 2013). ${ }^{17}$

Propensities to be in a given group of employment hours would then be calculated for all those in the potentially employable pool after the policy change. The most likely hours outcome predicted for an individual would be that resulting from the largest gain to employment after the policy change. Those for whom the most likely outcome is no employment would be excluded from the employment pool and therefore not considered suitable candidates for the new jobs in the matching process. Among those with positive predicted hours, the matching procedure with the newly created jobs would need to account not only for the industry and occupation but also the range of hours in each job. A "job" would thus be characterized by the trio industry, occupation, hours and the most likely job assigned to each individual would include the additional information on hours. ${ }^{18}$

Adapting the Levy method, the order in which candidates for the same job are considered could, for example, be the inverse of the likelihood of not being employed (the nonemployment outcome in the discrete choice model). As the number of jobs to allocate to candidates is limited, not necessarily all potential workers with predicted positive hours will receive a new job.

Then, with these imputed variables (hours, wages, industry, and occupation) available for the entire population of potential workers, the same matching procedure as the Levy method-hotdecking by affinity scoring on the nearest neighbor within specific cluster groups such as sex/age/education - would be used to allocate earnings.

Including supply-side effects of a policy would allow a fuller comparison between different investment scenarios; for example, as before between investment in care and in construction. In the method described above, investment in the direct provision of high-quality universal childcare will change the composition of the employable pool and thus impact the allocation of jobs whereas investing in construction will not do so since such investment is not expected to

\footnotetext{
${ }^{17}$ Different models could be used, such as the one described above (different hours clusters for those in employment, and thus conditional on being in employment) or a single pool of employed and employable people for which the discrete choices include one with zero hours of employment.

${ }^{18}$ Alternatively, a job could remain characterized by an industry/occupation pair, as in the IKK and AKMZ studies, with hours apportioned to each job reflecting the current distribution in the labor market (prior to the assignment).
} 
change caring constraints. ${ }^{19}$ Construction and physical infrastructure investment might change other forms of work-related costs/constraints, such as commuting time and cost. A more complex/complete model could take these into account when comparing the full effects of different investment policies.

\section{BEHAVIORAL CHANGES AMONG THOSE IN EMPLOYMENT}

The Levy method allocates jobs only to people not currently employed; it does not allow for any of those currently employed to change their jobs. The extension we have considered so far does the same and does not consider whether any of those currently employed would change their behavior as a result of the change in childcare provision. Moreover it implicitly assumes that those for whom caring constraints are alleviated would be candidates for only the jobs that were created, a majority of which are in the childcare sector. It is not straightforward that this would be the case in reality though. A more realistic model should account for the possibility that those currently in employment could also change their behavior depending on the specific childcare policy and its subsequent effects on the labor market. In particular, childcare constraints are known to be a reason why mothers choose to work part time, so that the model built above that accounts for changes in the net gain from employment at different hours should also allow for those in part-time employment wishing to be considered for a new full-time job.

However, investment in childcare provision may also reduce labor market involvement for those already in employment. For example, if childcare is provided for free and universally to all children regardless of their parents' employment status or income level, then the decision as to whether to take employment and for how many hours would no longer be influenced by the necessity to find and finance suitable childcare. It is possible that some people currently in (fulltime) employment might choose to reduce their hours if they no longer have to pay for childcare, and thus no longer need to earn as much to achieve the same standard of living - a typical income effect.

\footnotetext{
${ }^{19}$ Unless of course if we consider that substantial construction of affordable dwellings would allow extended families to live closer together (i.e., grandparents near their grandchildren) and help with care informally; however, these would be much more indirect effects.
} 
Similarly, but with a different policy scenario, if a limited number of high-quality affordable childcare places were offered, currently employed mothers might substitute such childcare for their less desirable existing childcare solutions, so that potential new entrants to the labor market experience no improved childcare offer. That such a result is plausible is shown by the findings of a study in Norway that found that making formal childcare more available was followed by little change in labor supply, as mothers already in employment simply substituted the newly available formal childcare for previous informal care (Havnes and Mogstad 2009).

Some papers, including one for Norway (Kornstad and Thoresen 2007) and one for the Belgian region of Flanders (Vanleenhove 2013), explicitly model labor supply and childcare decisions jointly in order to determine whether income or substitution effects dominate, although usually in unconstrained labor demand settings.

Another way in which those currently employed (even full time) might change their behavior is through the impact of the investment on wages. Wage levels have been considered exogenous to the whole investment process in both the ITUC and the Levy method papers. However this does not mean they are fixed, as they can still be changed exogenously. For example, knowing that a substantial investment in high-quality childcare services would require increased pay for childcare workers to ensure training and stability in the workforce, a public authority investing in such a service might raise wages of childcare workers employed in public or subsidized services toward those of primary school teachers (see De Henau [2016, 2019] for a discussion of the UK case). Wages in remaining private childcare services could be assumed to adapt quickly enough to be also considered as exogenous. ${ }^{20}$

If working conditions become substantially more attractive in a sector benefiting from the direct investment, this may have implications for other sectors. In particular, employees in other sectors might want to move to the new, more attractive jobs and will succeed in getting those jobs if they have more suitable characteristics than the pool of people not currently in employment. This possibility is also discussed in the AKMZ study, although it did not model such adjustment: in its

\footnotetext{
${ }^{20}$ Note that if childcare costs are subsidized through family cash transfers and not via direct provision with wage setting by the authority, then the impact on wages is endogenous to the changes in the overall labor market.
} 
model the new jobs were deemed to have the same characteristics with respect to hours, pay, and working conditions as the current jobs within similar occupation/industry clusters.

Further extension of the model could therefore allow for these relatively immediate behavioral changes by those already in employment. This would require a further modification of the assignment method by reallocating all jobs. The model would allow for the existing employed people to change jobs using their estimated propensities to be employed in another job, including for a higher wage. Each candidate, whether employed or in the employable pool, would be given their predicted values for industry, occupation, hours, and wages following the estimation procedure described above until all vacancies for each job are exhausted, with potentially all workers reallocated. The order of the allocation could be based on the highest likelihood of being in a specific job, as described above.

\section{SPENDING PATTERNS AND SHORT-TERM INDUCED EFFECTS}

In the ITUC study, calculations of employment creation included induced as well as direct and indirect effects, with the induced effects being the result of increased spending due to increases in household income assuming those getting the new jobs earned the same as those in existing jobs in the same industry. Household expenditure patterns were assumed uniform and unchanged, so that all households continued to spend in the same proportions as the national average, with households in which a member got a new job just spending more because of its increased income.

However, in the stylized facts above it was pointed that spending patterns might be expected to differ for income earned by men from income earned by women, and also for those at different levels of income. Although the job assignment method developed in the AKMZ and IKK studies calculates individual earning increases for those getting the new jobs, like other studies they do not exploit this information to analyze the impact on spending patterns and thus on induced employment effects. ${ }^{21}$ Therefore, a more refined induced effect calculation would require

\footnotetext{
${ }^{21}$ Interestingly, IKK develops its macro model to analyze the effects of a policy of increased cash transfer to lowincome families by splitting the spending of households in the input-output table into two groups and using their observed spending patterns (from another expenditure survey) to derive employment effects.
} 
investigating spending patterns of households likely to be affected by the policy changes, for example, the effects of having an additional employed man or woman on household income and thus its expenditure. Such more complex models have been proposed in the past, albeit in many different formats (see Bourguignon, Bussolo, and Cockburn [2010] for a review of micro-macro models). To provide the necessary data, the whole job allocation process and tax-benefit calculations could be done using consumption/expenditure surveys or, if they do not provide enough of the variables needed for the job allocation process, two different datasets could be used, provided some good matching variables can be identified to reconcile the two.

To recalculate the types of goods and services that households affected by income changes would purchase, various assumptions could be considered for changes in household spending patterns, in increasing order of complexity:

(1) That relative spending on goods and services does not change, only its level.

(2) That relative spending can change, but only in the sector affected by the investment (e.g., reduced or increased childcare spending).

(3) That relative spending does not change apart from the sector affected, but the marginal propensity to consume is affected by increased income.

(4) That relative spending and marginal propensity to consume are both allowed to change, for example, to reflect different spending patterns by households with a different gender composition of earners as well as by households at different levels of income.

In any of these cases, spending changes would then need to be fed back into the input-output calculations. This could be done by augmenting the input-output matrix with as many cells as needed to account for heterogeneity in household types. This would create an iteration process by which the spending patterns of those in the newly created jobs would influence the creation of further jobs to be allocated to other individuals, whose income and thus spending would also rise, and so forth until the equilibrium is attained. ${ }^{22}$

\footnotetext{
${ }^{22}$ This iteration process still assumes short-term/immediate adjustment mechanisms and price stability as well as no technological change, as in the macro-model described earlier.
} 
Note that a more complex model could also analyze changes in time spent on unpaid care and its gender composition to take account of changing gender norms and power relations in the division of labor and resources within households, which the increased supply of care services and increased employment opportunities for women could transform (Folbre and Nelson 2000). Although not concerned with demand-supply feedback effects, Masterson (2013) analyzed the impact of job creation not only on the earnings of those newly employed but also on their consumption and time use.

With all these variables in mind, distributional income effects can be calculated between households and potentially within households, too. Moreover, fiscal aggregates can be derived from the use of the tax-benefit model and consumption spending in order to assess revenue streams going back to the public authorities. It is entirely possible that much of the initial investment can be recouped when the economy has adjusted (even if only the short-term effects of the behavioral response are considered, such as those explained above). The sources of such revenue include:

- employer and employee social security contributions and income tax revenue from the increased earnings of the new jobs;

- indirect tax revenue from increased consumption (VAT, etc.); and

- reduced bill on social security benefits (both in-work and out-of-work, and, depending on the policy in place, childcare subsidies, if investment provides instead direct services)

In a more simplified model, De Henau (2019) shows that in the United Kingdom, increased tax revenue and reduced spending on social security benefits would potentially recoup between 76 percent and 79 percent of the cost of providing universal childcare for all preschool children, depending on the pay and qualification levels of childcare workers. 


\section{CONCLUSION}

This paper has discussed a method for analyzing gender effects of a specific investment policy simultaneously from both a demand- and a supply-side perspective. Building on existing models, including the methodology developed by the Levy Institute, we have examined the ways in which existing analytical tools would need to be adapted to carry out a fuller analysis of the short-term effects of investment on gender inequalities in employment, earnings, income, and time use.

Using the example of public investment in the social infrastructure, in particular (child)care services, and comparing it with investment in a nonsocial industry such as construction, this paper has illustrated the ways in which accounting for a series of different elements of the demand and supply sides may alter the gendered outcomes in terms of employment levels and segregation.

Significant public investment in care services has been shown to create a larger number of jobs, especially for women, than equivalent investment in other industries such as construction, while at the same time reducing many constraints on unpaid carers' employment possibilities. These results, confirmed by the analysis done for the ITUC, should not be used to argue that investment in construction is not worthwhile. Rather, since at least as large employment effects can also be generated by investment in care, with particularly beneficial gender equality effects, the case for which type of investment should be made has to depend on what benefit the results of each type of investment would in itself generate for society. It can no longer be made on the grounds that investing in physical infrastructure is the best way to stimulate employment.

The paper has also argued that in order to understand the fuller impact on gender inequalities in employment, including effects on earnings and incomes, explicitly modeling labor supply responses is necessary, as changes in care constraints may improve employment opportunities for many, but may also reduce the need to work long hours for others. 
The next research step would be to operationalize such a model and to carry out empirical analysis and policy simulations of different scenarios of investment in care services. However, while it is important to model and analyze the indirect benefits of investment, they should not be allowed to overshadow the main reason for considering investing public money in social infrastructure: the direct benefits that it brings for people in being healthier, better cared for, and better educated. That public investment in physical infrastructure tends to be justified in more instrumental terms of benefits to "the economy" does not mean that the social sector has to be seen in the same way.

These are arguments made time and again by feminist economists (Elson, Campbell, and McKay 2013), organizations such as the Women's Budget Group in their feminist "Plan F" for recovery, and supporters of the purple economy (Ilkkaracan 2013), who also recognize that society depends on care as "an indispensable component of human well-being” (Ilkkaracan 2013, 32) and therefore the public provisioning of social infrastructure is crucial for economic, social, and human development. 


\section{REFERENCES}

Adams, S., and D. Phillips. 2013. "An ex-ante analysis of the effects of the UK government's welfare reforms on labour supply in Wales.” Research Report R75. London: Institute for Fiscal Studies

Antonopoulos, R., and K. Kim. 2008. "Impact of Employment Guarantee Programmes on Gender Equality and Pro-poor Economic Development." Policy Brief: Case Study on South Africa. Annandale-on-Hudson, NY: Levy Economics Institute of Bard College.

Antonopoulos, R., K. Kim, T. Masterson, and A. Zacharias. 2011. "Investing in Care: A Strategy for Effective and Equitable Jobs." Levy Institute Working Paper No. 610. Annandale-onHudson, NY: Levy Economics Institute of Bard College.

Apps, P., and R. Rees. 2004. "Fertility, Taxation and Family Policy.” The Scandinavian Journal of Economics 106(4): 745-63.

- 2005 "Time Use and the Costs of Children over the Life Cycle." In D. Hamermesh and G. Phann (eds.), The Economics of Time Use. London: Elsevier.

Baumol, W., and W. E. Oates. 1972. "The cost disease of the personal services and the quality of life." Skandinaviska Enskilda Banken Quarterly Review 2: 44-54.

Bourguignon, F., M. Bussolo, and J. Cockburn. 2010. "Macro-Micro Analytics: Background, Motivation, Advantages and Remaining Challenges." International Journal of Microsimulation 3(1): 1-7.

Braunstein, E., I. van Staveren, and D. Tavani. 2011. "Embedding care and unpaid work in macroeconomic modelling: a structuralist approach." Feminist Economics 17(4): 5-31.

Budig, M. J., and J. Misra. 2010. "How care-work employment shapes earnings in cross-national perspective." International Labour Review 149(4): 441-60.

De Henau, J. 2016. "Costing a Feminist Plan for a Caring Economy: The Case of Free Universal Childcare in the UK." In H. Bargawi, G. Cozzi, and S. Himmelweit (eds.), Lives after Austerity: gendered impacts and sustainable alternatives for Europe. London: Routledge.

- 2019. "Employment and fiscal effects of investing in universal childcare: a macro-micro simulation analysis for the UK" IKD Working Paper 83. Milton Keynes, UK: Open University. Available at: http://www.open.ac.uk/ikd/publications/working-papers/83

De Henau, J., S. Himmelweit, Z. Łapniewska, and D. Perrons. 2016. "Investing in the Care Economy: A gender analysis of employment stimulus in seven OECD countries." A report by the UK Women's Budget Group, Commissioned by the International Trade Union Congress. London: Women's Budget Group. Available at: http://www.ituccsi.org/IMG/pdf/care_economy_en.pdf 
De Henau, J., S. Himmelweit, and D. Perrons. 2017. "Investing in the Care Economy: Simulating employment effects by gender in countries in emerging economies." A report by the UK Women's Budget Group, Commissioned by the International Trade Union Congress and UN Women. London: Women's Budget Group. Available at: https://www.ituc-csi.org/IMG/pdf/care_economy_2_en_web.pdf

De Henau, J., and S. Himmelweit. 2013a. "Unpacking within-household gender differences in partners' subjective benefits from household income." Journal of Marriage and Family 75(3): 611-24.

. 2013b. "Examining public policy from a gendered intra-household perspective: changes in family-related policies in the UK, Australia and Germany since the mid-nineties." Oñati Socio-Legal Series 3(7).

De Henau, J., D. Meulders, and S. O’Dorchai. 2010. "Maybe Baby: Comparing Mothers' Employment and Child Policies in the EU-15." Feminist Economics 16(1): 4377

Del Boca, D., and S. Pasqua. 2005. "Labour Supply and Fertility in Europe and the U.S." In T. Boeri, D. Del Boca, and C. Pissarides (eds.), Women at Work: An Economic Perspective. Oxford: Oxford University Press.

Del Boca, D., and D. Vuri. 2007. "The Mismatch between Labor Supply and Child Care." Journal of Population Economics 20(4): 805-32.

Duncan, A., C. Giles, and J. MacCrae. 1999. "Household Labour Supply, Childcare Costs and In-Work Benefits: Modelling the Impact of the Working Families Tax Credit in the UK." Mimeo. London: Institute for Fiscal Studies.

Elson, D. 1995. “Gender Awareness in Modeling Structural Adjustment.” World Development 23(11): 1851-68

Elson, D., J. Campbell, and A. McKay. 2013. "The Economic Case for Investing in High Quality Childcare and Early Years Education." Women in Scotland's Economy (WISE) Briefing Sheet, November. Glasgow: Glasgow Caledonian University. Available at: http://www.gcu.ac.uk/media/gcalwebv2/theuniversity/centresprojects/wise/04_WiSEbrief ingpaper_Nov13.pdf

England, P. 2005. "Emerging Theories of Care Work.” Annual Review of Sociology 31: 381-99.

England, P., M. Budig, and N. Folbre. 2002. "Wages of Virtue: The Relative Pay of Care Work." Social Problems 49(4): 455-73.

European Commission. 2010. "Strategy for Equality between women and men 2010-2015." Communication from the Commission (COM 491 final, 21.9.2010). Brussels: European Commission.

Folbre, N., and J. A. Nelson, J.A. 2000. "For love or money-or both?” Journal of Economic Perspectives 14(4): 123-40. 
Fontana, M., and Y. van der Meulen Rodgers. 2005. "Gender Dimensions in the Analysis of Macro-Poverty Linkages.” Development Policy Review 23(3): 333-49.

Havnes, T., and M. Mogstad. 2009. "Money for Nothing? Universal Child Care and Maternal Employment.” IZA Discussion Paper No. 4504. Bonn: Institute of the Study of Labor (IZA).

Heckman, J., S. H. Moon, R. Pinto, P. A. Savelyev, and A. Q. Yavitz. 2010. “Analyzing Social Experiments as Implemented: A Reexamination of the Evidence from the High Scope Perry Preschool Program." Quantitative Economics 1(1): 1-46.

Heckman, J., R. Pinto, and P. A. Savelyev. 2013. "Understanding the Mechanisms through Which an Influential Early Childhood Program Boosted Adult Outcomes." American Economic Review 103(6): 2052-86.

Himmelweit, S. 2002. "Making Visible the Hidden Economy: The Case for Gender-Impact Analysis of Economic Policy." Feminist Economics 8(1): 49-70.

- 2007. "The prospects for caring: economic theory and policy analysis." Cambridge Journal of Economics 31(4): 581-99.

- 2016. "Childcare as an Investment in Infrastructure.” In J. Campbell and M. Gillespie (eds.), Feminist Economics and Public Policy: Reflections on the work and impact of Ailsa McKay. Abingdon and New York: Routledge.

Ilkkaracan, I., K. Kim, and T. Kaya. 2015. “The Impact of Public Investment in Social Care Services on Employment, Gender Equality and Poverty: The Turkish Case." Levy Institute Research Project Report, August. Annandale-on-Hudson, NY: Levy Economics Institute of Bard College.

Ilkkaracan, I. 2013. "The Purple Economy: A Call for a New Economic Order Beyond the Green Economy." In Sustainable Economy and Green Growth: Who Cares? International Workshop Linking Livelihood and Sustainable Economy. Berlin: Genanet.

Kornstad, T., and T. Thoresen. 2007. "Discrete choice model for labour supply and childcare." Journal of Population Economics 20(4): 781-803.

Masterson, T. 2013. "Quality of Statistical Match and Simulations Used in the Estimation of the Levy Institute Measure of Time and Consumption Poverty (LIMTCP) for Turkey in 2006." Levy Institute Working Paper No. 769. Annandale-on-Hudson, NY: Levy Economics Institute of Bard College.

Onaran, O. 2016. "The Role of Gender Equality in an Equality-led Sustainable Development Strategy.” In H. Bargawi, G. Cozzi, and S. Himmelweit (eds.), Lives after Austerity: gendered impacts and sustainable alternatives for Europe. London: Routledge.

Phillips, A., and B. Taylor. 1980. "Sex and skill: notes towards a feminist economics." Feminist Review 6(1): 79-88. 
Reed, H., and J. Portes. 2014. “Cumulative Impact Assessment: A Research Report by Landman Economics and the National Institute of Economic and Social Research (NIESR) for the Equality and Human Rights Commission." Equality and Human Rights Commission Research Report No. 94. Manchester, UK: Equality and Human Rights Commission.

Seguino, S. 2000. "Gender inequality and economic growth: A cross-country analysis." World Development 28(7): 1211-30.

- 2013. "From micro-level gender relations to the macro economy and back again." In D. Figart and T. Warnecke (eds.), Handbook of Research on Gender and Economic Life. Cheltenham, UK: Edward Elgar.

Toner, P. 2006. "Restructuring the Australian construction industry and workforce: implications for a sustainable labour supply." Economic and Labour Relations Review 17(1).

Vanleenhove, P. 2013. "Full Childcare Coverage: Higher Maternal Labour Supply and Childcare Usage?" EUROMOD Institute for Social and Economic Research Working Paper No. EM/19/13. Essex, UK: EUROMOD.

Zacharias, A., T. Masterson, and K. Kim. 2014. "The Measurement of Time and Income Poverty in Korea: Final Report.” Levy Institute Research Project Report, August. Annandale-onHudson, NY: Levy Economics Institute of Bard College. 